\title{
A Study on Traveler Expectation, Motivation and Attitude
}

\author{
Macy Wong \\ The Hong Kong Polytechnic University \\ E-Mail: spmacy@speed-polyu.edu.hk \\ Ronnie Cheung \\ University of South Australia \\ E-Mail: ccheung@acm.org \\ Calvin Wan \\ The Hong Kong Polytechnic University \\ E-Mail: spcalvin@speed-polyu.edu.hk
}

\begin{abstract}
The travel and tourism sector has been a major contributor to the Hong Kong economy over the past decades. Both inbound and outbound tourism has had a steady growth in travelers. A local newspaper reported that Hong Kong residents are expected to travel aboard at least six times every two years. Drawing upon an expectation, motivation, and attitude (EMA) model, this study examined the correlation between traveler expectation, attitude and motivation for visiting an outbound destination. A questionnaire survey collected 137 responses. The findings showed a significant correlation between traveler expectations and motivation, as well as motivation and attitude. In addition, traveler knowledge is statistically correlated with the expectation.
\end{abstract}

Keywords: Hong Kong Travel and Tourism Sector, Traveler Expectations and Motivation, Traveler Attitude 


\section{INTRODUCTION}

The travel and tourism sector has been a major contributor to the economy of Hong Kong over the past decades, together with financial services, trading and logistics, and producer and professional services (Census and Statistics Department, 2010). Indeed, there has been a significant increase in tourists from mainland China due to the introduction of the Individual Visit Scheme (IVS) in 2003 (Tourism Commission, 2006). In 2009, mainland China (60.7\%), Taiwan (6.8\%) and Japan (4.1\%) remained the top-three source markets generating the most visitors to Hong Kong.

In addition to the inbound tourism, outbound tourism contributed HK\$7.3 billion ( $0.5 \%$ of GDP) in 2008. Although the GDP contribution of inbound tourism is higher than that of outbound tourism in Hong Kong, the stamp duty revenue in the first three quarters of 2010 for outbound tourism increased by 36\% in comparison with the same period in 2009. The total number of air ticket sales increased by HK\$4.3 million in first nine months of 2010, which is an increase of around 550,000 tickets from the same period in 2009 (Oriental Daily, 2010). A local newspaper reported that a research study indicated that $48 \%$ of respondents will extend their travel plans or decide to travel to less expensive locations due to a difficult economy. Travelers tended to have an average of three outbound tours each year (Sing Tao, 2010) and low cost carriers are popular among young travelers (Sum and Cheung, 2013) in Hong Kong.

According to a recent article, a tourist behavior model has been developed, called the expectation, motivation and attitude (EMA) model (Hsu et al., 2010). This model focuses on the pre-visit stage of tourists by modeling the behavioral process by incorporating expectation, motivation, and attitude. Travel motivation is considered as an essential component of the behavioral process, which has drawn increasing attention from the travel industry. This paper aims to investigate the correlation between Hong Kong travelers' expectations, attitudes and motivations. The results provide insights to practitioners in the travel and tourism sector.

\section{LITERTURE REVIEW}

Hong Kong shifted to a service-sector model in the early 1990s, and tourism is an important service sector with steady growth (Census and Statistics Department, 2010). According to Leiper (1979, p. 391), tourism is "the theory and practice of touring, travelling for pleasure”. Indeed, the term 'tourism' can be defined by considering different approaches. The economic approach defines "tourism is an identifiable 
nationally important industry. The industry involves a wide cross section of component activities including the provision of transportation, accommodation, recreation, food, and related service" (Australian Department of Tourism and Recreation, 1975, p. 2). Based on a holistic approach, tourism embraces a whole essence of a subject. Jafari (1977, p. 8) considers that "tourism is the study of man away from his usual habitat, of the industry which responds to his needs, and of the impacts that both he and the industry have on the host's socio-cultural, economic and physical environments”.

\section{Travel Motivation}

Travel motivation has gained considerable attention from tourism academia since the 1960s to better understand and predict factors that influence travel decision-making (Kim, et al., 2007). According to Backman and others (1995, p. 15), motivation is conceptually viewed as "a state of need, a condition that serves as a driving force to display different kinds of behavior toward certain types of activities, developing preferences, arriving at some expected satisfactory outcome”. This driving force has dominated travel patterns to protect and satisfy one's desire, and to increase the self-value of an individual (Lee and Chen, 2005).

By reviewing the past literature on tourist motivation, several theories or models have been developed to guide the empirical study of travel motivation, including push-pull (Dann, 1977); escape-seeking (Dunn and Iso-Ahola, 1991); and travel career ladder (Pearce, 1988). Particularly, the push and pull theory provides an important theoretical framework (Dann, 1977; Klenosky, 2002). Simply, push forces 'considering whether to go' (i.e., the desire to travel), while pull forces associate with the decision 'where to go' (i.e., the choice of destination) (Kim, et al., 2007). Based on the push and pull approach, people are pushed by internal desires, such as personal escape, psychological or physical health, thrill and adventure, and social interactions (Baloglu and Uysal, 1996). Subsequently, they are then pulled by external resources, such as, natural or artificial attractions that a destination may possess (Cha, et al., 1995). It is worth noting that the two sets of forces are dependent, thus, peoples' decisions to travel are formed consciously or unconsciously in a two-stage sequence (Kim, et al., 2007). 


\section{Tourist Expectations}

Vroom's (1964) expectancy model is prominent in explaining motivation, and it represents the psychological needs to pursuit a goal state. The two conditions for this pursuit are: 1) it must be possible to anticipate the occurrence of the goal state so there must be an expectation; and 2) the goal state must have some intrinsic value or attractiveness (valence) and it serves as a motive (Heckhausen, 1989). Thus, the relationship between motivation and expectation is that motivation can be conceptualized as the product of expectancy and valence (Hsu, et al., 2010). Motivation can be influenced by manipulating cues of an individual's expectation concerning the consequences of his/her action and/or the incentive value of the consequences produced by the action (Hsu, et al., 2010). A recent research study carried out by Lee, Jeon and Kim (2011) proved the correlation between tourist expectation and travel motivation. Interestingly, when tourists have high expectations, they are more willing to search for tour information, acquire knowledge regarding the destination culture, and other information (Lee, et al., 2011).

\section{Attitude}

Attitude is one of the critical constructs in understanding tourist motivation and behavior (Gnoth, 1997). According to Fishbein and Ajzen (1975:10), attitude is "a learned predisposition to respond in a consistently favorable or unfavorable manner with respect to a given object”. Although Fishbein and Ajzen (1975) did not propose a causal relationship between motivation and attitude, their theory did suggest that motivation precedes attitude, and the former may influence the latter (Hsu, et al., 2010). Further, Gnoth (1997) proposes that a tourist's attitude toward an object is determined by his or her felt needs and value system, highlighting the relationship between motivation and attitude. A more recent study by Lam and Hsu (2004, 2006) attempted to predict travel behavior and intention of destination selection. They postulated that tourists' behavior belief of motivational factors is a determinant of their affective dimension of attitude toward visiting Hong Kong.

Apart from considering motivation and attitude, it is of value to examine the relationship between expectation and attitude. Indeed, expectation is a variation of belief in a specific context, and attitude can be determined by ones' expectation of a specific object (Hsu, et al., 2010). This thinking is in agreement with Higgins (1996) and Olson, Roese, and Zanna (1996) ideas that expectation is a proxy of belief in attitudinal studies. 


\section{Expectation, Motivation and Attitude (EMA) Model}

The Expectation, Motivation, and Attitude (EMA) Model proves interrelations between and among expectation, motivation, and attitude by using data collected from potential mainland Chinese outbound tourists (Hsu et al., 2010). The EMA model is primarily based on the theoretical study by Gnoth (1997) and it identifies four factors that are constructs of motivation, including knowledge, relaxation, novelty and shopping. The results of this study confirmed the proposed relations: (1) expectation of visiting an outbound destination has a direct effect on motivation to visit the destination; (2) motivation has a direct effect on attitude toward visiting the destination; (3) expectation of visiting the outbound destination has a direct effect on attitude toward visiting the destination; and (4) motivation has a mediating effect on the relationship in between expectation and attitude.

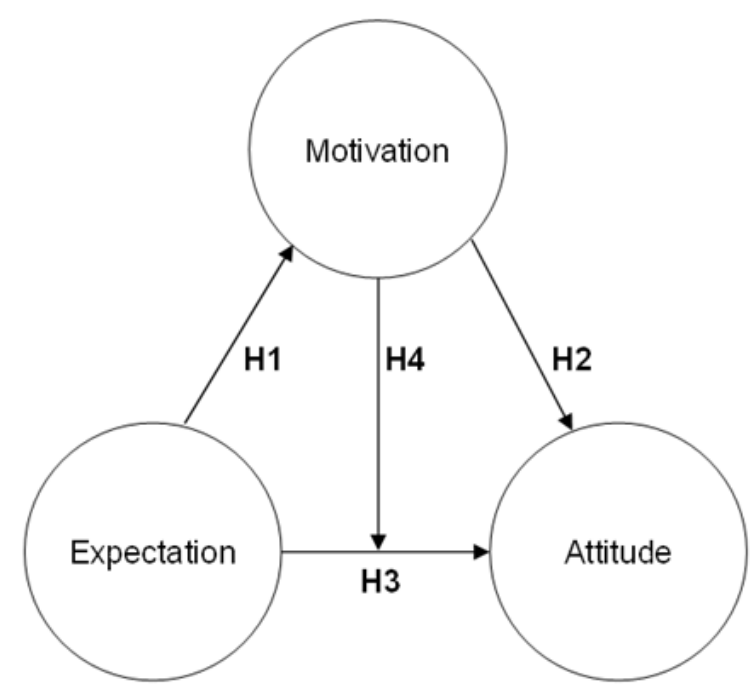

Figure 1 The EMA Model (Hsu et al., 2010; Gnoth, 1997)

According to Yoon and Uysal (2005), tourist travel is mainly driven by two motivational aspects, which are push factors and pull factors. The push factors refer to the psychological force that influences tourist choices about "excitement" or "relaxation". The pull factors include the external forces of the destination attributes, for example, environment of the destination or culture of the country. This study proves that push and pull factors have a direct effect on tourist satisfaction (Figure 2). Furthermore, most push factors are intangible or intrinsic desires of the individual travelers, while pull factors are those emerged as a result of the attractiveness of a destination, and thus these factors include tangible resources and traveler perceptions 
and expectations (Mohammad and Som, 2010). A general conclusion can be drawn that push motives and pull motives determine perceptions (Mohammad and Som, 2010), and these motives interact in a dynamic and evolving context and tourist motivation can be thought of as a multidimensional concept can help to explain tourist decisions (McCabe, 2000).

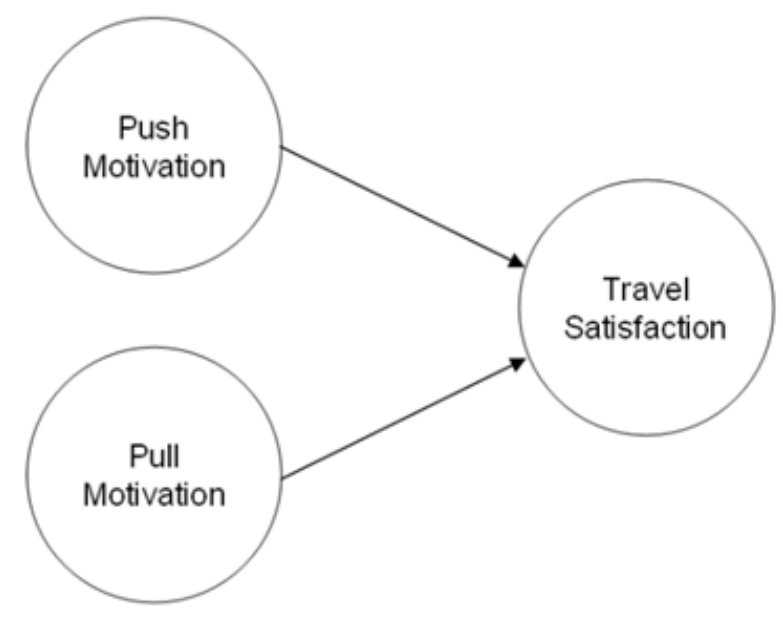

Figure 2 Motivational Drivers (Yoon and Uysal, 2005)

\section{RESEARCH OBJECTIVES AND HYPOTHESES}

This paper aims to examine the proposed correlations of the EMA Model that the expectation of visiting a certain outbound destination has a direct effect on motivation to visit the destination; motivation has a direct effect on attitude toward visiting a certain destination; and that expectation of visiting a certain outbound destination has a direct effect on attitude.

Drawing up upon the literature above, the following hypotheses are proposed and are subsequently tested empirically. The conceptual framework is illustrated in Figure 3.

Considering the majority of previous studies, this study has identified the key motives of travelers in making travel decisions - knowledge, excitement, relaxation, friends and family, and shopping. As such, this current research has considered motivation as being multi-dimensional. According to Jacob and Ragheb (1983), people's motives cannot be explained by a single-dimension as people have different reasons for engaging in leisure or travel activities. 


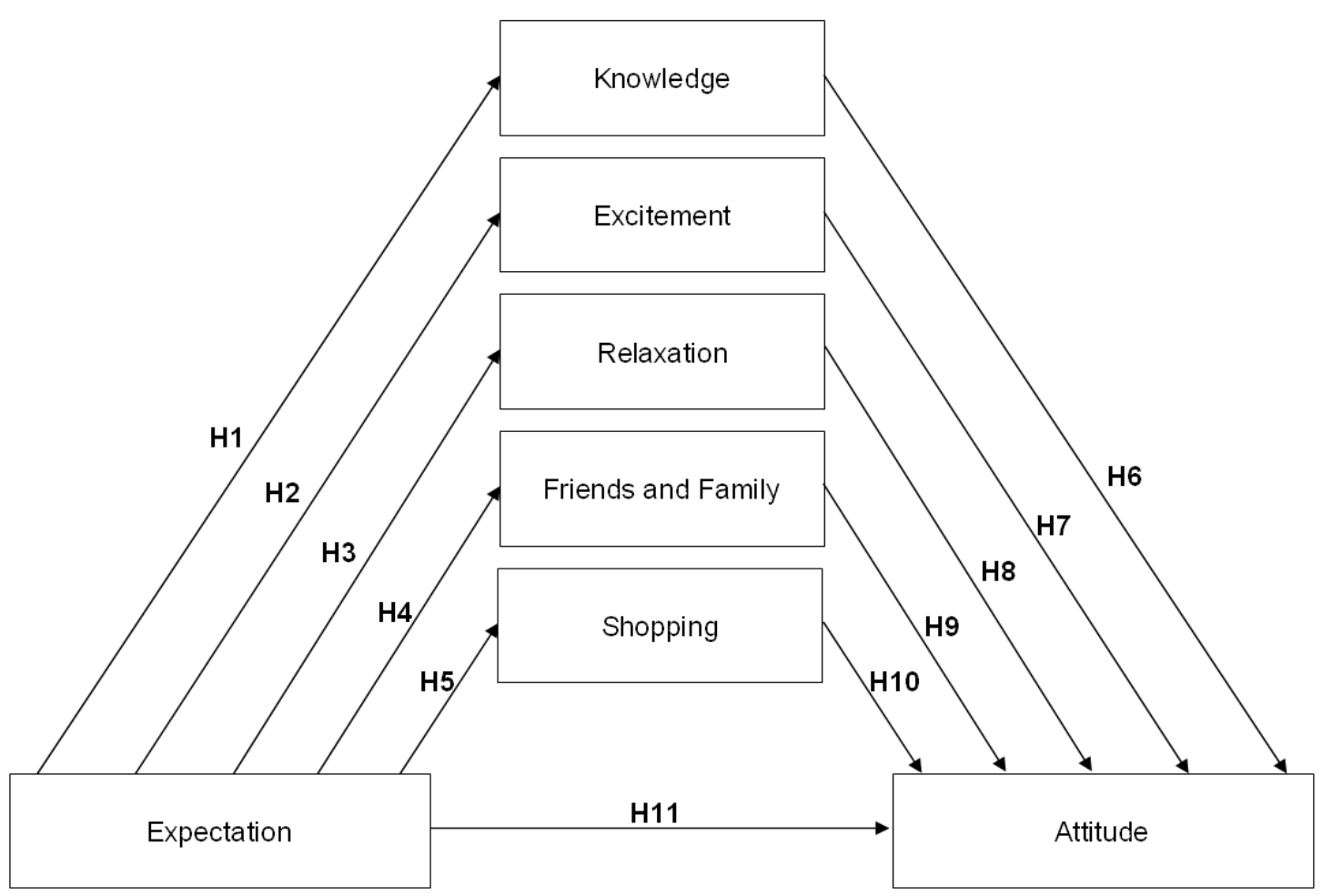

Figure 3 Research Framework

H1: Tourists' expectation of visiting an outbound destination has a positive relationship on their knowledge to visit the destination.

H2: Tourists' expectation of visiting an outbound destination has a positive relationship on their excitement to visit the destination.

H3: Tourists' expectation of visiting an outbound destination has a positive relationship on their relaxation to visit the destination.

H4: Tourists' expectation of visiting an outbound destination has a positive relationship on their friends and family to visit the destination.

H5: Tourists' expectation of visiting an outbound destination has a positive relationship on their shopping to visit the destination.
H7: Tourists' excitement has a positive relationship on their attitude toward visiting the destination.

H8: Tourists' relaxation has a positive relationship on their attitude toward visiting the destination.

H9: Tourists' friends and family have a positive relationship on their attitude toward visiting the destination.

H10: Tourists' shopping has a positive relationship on their attitude toward visiting the destination.

H11: Tourists' expectation has a positive relationship on their attitude toward visiting the destination.

H6: Tourists' knowledge has a positive relationship on their attitude toward visiting the destination. 


\section{METHODOLOGY}

Drawing upon the literature, there are various measurement items for motivation, expectation and attitude, which are based on the literature review and are used to measure the constructs of motivation, expectation and attitude (as shown in Table 1).

The questionnaire consists of four major sections covering travel motivation, expectation and attitude, and demographic information. In order to enhance internal validity, pre-testing was used to modify the questionnaire before launching the survey. 25 questionnaires were randomly distributed to respondents in the pilot test, and this resulted in some wording refinements in the questionnaire. An online questionnaire was established, 140 respondents completed the questionnaire and 137 of these were valid.

Table 1 Conceptual Definition of Constructs

\begin{tabular}{|c|c|c|}
\hline Constructs & Conceptual Definitions & Sources \\
\hline Expectation & $\begin{array}{l}\text { Conviction that one can successfully execute the } \\
\text { behavior required to produce the outcomes }\end{array}$ & Bandura (1977) \\
\hline Attitude & $\begin{array}{l}\text { Consists of beliefs about the consequences of } \\
\text { performing the behavior multiplied by his or her } \\
\text { valuation of these consequences. }\end{array}$ & $\begin{array}{l}\text { Ajzen and Fishbein } \\
(1975)\end{array}$ \\
\hline Knowledge & An external motive involved mental representation & Yoon and Uysal (2005) \\
\hline Relaxation & $\begin{array}{l}\text { The relaxation usually means physical rest. In a } \\
\text { tourism context, however, relaxation often means } \\
\text { taking time to pursue activities of interest for tourist } \\
\text { engaging in physical activities often result in mental } \\
\text { relaxation }\end{array}$ & $\begin{array}{l}\text { Hsu, Cai and Li (2010) } \\
\text { Crompton (1979) }\end{array}$ \\
\hline Novelty & $\begin{array}{l}\text { Change from routine, escape, thrill, adventure, } \\
\text { surprise and boredom alleviation }\end{array}$ & Berlyne (1950) \\
\hline Shopping & $\begin{array}{l}\text { Consumer behavior to select or purchase, considered } \\
\text { as leisure activity }\end{array}$ & Hsu, Cai and Li (2010) \\
\hline
\end{tabular}


Table 2 Respondents’ Profile

\begin{tabular}{l|c|l|c}
\hline Characteristics & $\boldsymbol{\%}$ & Characteristics & \% \\
\hline Age & & Education & \\
$19-29$ & 51.8 & Primary or below & 3.6 \\
$30-39$ & 27.7 & Secondary & 30.7 \\
$40-49$ & 13.9 & Post-secondary & 18.2 \\
$50-59$ & 5.8 & Bachelor degree & 43.8 \\
$>60$ & 0.7 & Master degree or above & 3.6 \\
\hline Age Categories & & Marital Status & \\
$19-29$ & 51.8 & Single & 70.8 \\
$>30$ & 48.2 & Married & 28.5 \\
& & Widowed & 0.7 \\
\hline Gender & & Number of Family Members & 46.3 \\
Male & 47.4 & 3 & \\
Female & 52.6 & $>4$ & \\
\hline
\end{tabular}

The respondents who completed the questionnaire were evenly distributed in terms of gender: male (47.4\%) and female (52.6\%), and the majority were single (70.8\%). All the respondents were Hong Kong residents, and more than $51.8 \%$ of respondents were between 19 and 29 years-old. The profile of respondents is shown in Table 2 below.

\section{DATA ANALYSIS}

In the questionnaire, we have adopted a 5-point Likert scale that was defined as: (1) strongly disagree, (2) disagree, (3) neutral, (4) agree and (5) strongly agree. Factor analysis was applied to group the Likert-scale variables into a small number of interpretable underlying factors. According to the EMA model study (Hsu et al., 2010) and a study of an examination of the effects of motivation and satisfaction (Yoona and Uysal 2005), a total of 27 items were listed to extract underlying dimensions of motivation, and expectation and attitudes respectively (see Table 3).

A Kaiser eigenvalue criterion is used to decide on how many factors to retain before proceeding with analysis (Nunnally and Bernstein, 1994). Factors with eigenvalues greater than one are retained and factors with eigenvalues less than one 
are considered insignificant and therefore excluded. Each measurement item is only under one component and is not overlapped to another component (Hsu et al., 2010; Yonna and Uysal, 2005). The Rotation Method is Varimax with Kaiser Normalization. The cut-off value of factor loading should be greater than 0.5 (Nunnally and Bernstein, 1994). Seven components were retained in the factor analysis, however, loadings for some of the items were below 0.5 , which were considered as weak items, and were eliminated in the model. In the reliability analysis, the Cronbach's alpha for each factor is computed in order to test the reliability of the item variables. The reliability coefficients for all the items were above 0.7, showing that all the items in the constructs were above the generally acceptable low limit for the reliability coefficient (Hair et al., 1998). The 7 factors were retained and renamed as constructs in the EMA Model (see Table 2).

Bivariate correlation analysis was carried out in order to explore the correlations between these seven factors (as shown in Table 4). A strong relationship between expectation and knowledge $(r=.660, \mathrm{p}<0.01)$ was found. In addition, there was a strong relationship between attitude and knowledge $(r=.292$, p $<0.01)$, excitement $(r$ $=.229, \mathrm{p}<0.01)$, relaxation $(\mathrm{r}=.294, \mathrm{p}<0.01)$ and shopping $(\mathrm{r}=.230, \mathrm{p}<0.01)$ (see Table 4).

Expectation reflects the variations in beliefs. To apply this in the travel industry, we used expectation as an independent variable to test the travel motivation of Hong Kong travelers and to show if there is a direct effect towards those motivations or not. Motivation has been referred to as psychological or biological needs and as the wants of consumers. Under travel motivation, there were a total of 5 constructs, including Knowledge, Excitement, Relaxation, Friends and Family, and Shopping. Motivation is theoretically influenced by expectation and thus it would affect the attitude of tourists.

There is a very strong relationship between tourists' expectation and their knowledge. As tourists' expectation mainly reflected the beliefs of tourists, most expect that travel will result in learning new knowledge and exposure to beautiful scenes, etc. Therefore, H1 was accepted. H2, H3, H4 and H5 were rejected. This result reflects that expectation does not directly correlate with motivation, especially for the excitement, relaxation, friends and family, and shopping. This illustrates that tourists from Hong Kong tend to expect to learn knowledge from a travel experience, rather than thinking of travel as important for other purposes. 
Table 3 Factor Analysis

\begin{tabular}{|c|c|c|}
\hline Items & Loading & Cronbach's alpha \\
\hline $\begin{array}{l}\text { Component 1: Knowledge } \\
\text { Experiencing new/different lifestyles } \\
\text { Broadening their horizons } \\
\text { Blending into local culture } \\
\text { Visiting historical places } \\
\text { Satisfy the curiosity of the destination } \\
\text { Sight-seeing }\end{array}$ & $\begin{array}{l}0.807 \\
0.799 \\
0.683 \\
0.753 \\
0.637 \\
0.782\end{array}$ & 0.857 \\
\hline $\begin{array}{l}\text { Component 2: Excitement } \\
\text { Being Physical enjoyed } \\
\text { Meeting people of opposite sex } \\
\text { Feeling excited } \\
\text { Challenging own self } \\
\text { Getting away from the demands at home } \\
\text { Like Adventure }\end{array}$ & $\begin{array}{l}0.606 \\
0.622 \\
0.729 \\
0.708 \\
0.551 \\
0.770\end{array}$ & 0.786 \\
\hline $\begin{array}{l}\text { Component 3: Relaxation } \\
\text { Releasing working pressure } \\
\text { Getting a chance from a busy job } \\
\text { Relaxing own self }\end{array}$ & $\begin{array}{l}0.877 \\
0.882 \\
0.831\end{array}$ & 0.913 \\
\hline $\begin{array}{l}\text { Component 4: Friends and Family } \\
\text { Visiting home country } \\
\text { Visiting friends and relatives }\end{array}$ & $\begin{array}{l}0.902 \\
0.886\end{array}$ & 0.818 \\
\hline $\begin{array}{l}\text { Component 5: Shopping } \\
\text { Can buy well-known name product } \\
\text { Like shopping }\end{array}$ & $\begin{array}{l}0.922 \\
0.902\end{array}$ & 0.834 \\
\hline $\begin{array}{l}\text { Component 6: Expectation } \\
\text { Can learn new knowledge and culture } \\
\text { Can experience different things } \\
\text { Can see the beautiful view }\end{array}$ & $\begin{array}{l}0.885 \\
0.847 \\
0.761\end{array}$ & 0.853 \\
\hline $\begin{array}{l}\text { Component 7: Attitude } \\
\text { Satisfaction } \\
\text { Happiness } \\
\text { Enjoyment } \\
\text { Worthiness } \\
\text { Attractiveness }\end{array}$ & $\begin{array}{l}0.845 \\
0.836 \\
0.860 \\
0.567 \\
0.733\end{array}$ & 0.815 \\
\hline
\end{tabular}


Table 4 Bivariate Correlation

\begin{tabular}{|c|c|c|c|c|c|c|c|c|}
\hline & & Attitude & $\begin{array}{l}\text { Expect- } \\
\text { ation }\end{array}$ & $\begin{array}{l}\text { Know- } \\
\text { ledge }\end{array}$ & $\begin{array}{l}\text { Excite- } \\
\text { ment }\end{array}$ & $\begin{array}{l}\text { Relax- } \\
\text { ation }\end{array}$ & $\begin{array}{l}\text { Friend \& } \\
\text { Family }\end{array}$ & Shopping \\
\hline $\begin{array}{l}\text { Friend \& } \\
\text { Family }\end{array}$ & $\begin{array}{l}\text { Pearson } \\
\text { Correlation } \\
\text { Sig. (2-tailed) } \\
\mathrm{N}\end{array}$ & $\begin{array}{l}-.052 \\
.550 \\
137\end{array}$ & $\begin{array}{l}.048 \\
.579 \\
137\end{array}$ & $\begin{array}{l}.000 \\
1.000 \\
137\end{array}$ & $\begin{array}{l}.000 \\
1.000 \\
137\end{array}$ & $\begin{array}{l}.000 \\
1.000 \\
137\end{array}$ & 137 & $\begin{array}{l}.000 \\
1.000 \\
137\end{array}$ \\
\hline Shopping & $\begin{array}{l}\text { Pearson } \\
\text { Correlation } \\
\text { Sig. (2-tailed) } \\
\mathrm{N}\end{array}$ & $\begin{array}{l}.007 \\
137\end{array}$ & $\begin{array}{l}.094 \\
137\end{array}$ & $\begin{array}{l}1.000 \\
137\end{array}$ & $\begin{array}{l}1.000 \\
137\end{array}$ & $\begin{array}{l}1.000 \\
137\end{array}$ & $\begin{array}{l}.000 \\
1.000 \\
137\end{array}$ & 137 \\
\hline Attitude & $\begin{array}{l}\text { Pearson } \\
\text { Correlation } \\
\text { Sig. (2-tailed) } \\
\mathrm{N}\end{array}$ & 137 & $\begin{array}{l}1.000 \\
137\end{array}$ & $\begin{array}{l}.001 \\
137\end{array}$ & $\begin{array}{l}.007 \\
137\end{array}$ & $\begin{array}{l}.000 \\
137\end{array}$ & $\begin{array}{l}.550 \\
137\end{array}$ & $\begin{array}{l}.007 \\
137\end{array}$ \\
\hline Expectation & $\begin{array}{l}\text { Pearson } \\
\text { Correlation } \\
\text { Sig. (2-tailed) } \\
\mathrm{N}\end{array}$ & $\begin{array}{l}.000 \\
1.000 \\
137\end{array}$ & 137 & $\begin{array}{l}.000 \\
137\end{array}$ & $\begin{array}{l}.607 \\
137\end{array}$ & $\begin{array}{l}.823 \\
137\end{array}$ & $\begin{array}{l}.579 \\
137\end{array}$ & $\begin{array}{l}-.144 \\
.094 \\
137\end{array}$ \\
\hline Knowledge & $\begin{array}{l}\text { Pearson } \\
\text { Correlation } \\
\text { Sig. (2-tailed) } \\
\mathrm{N}\end{array}$ & $\begin{array}{l}.001 \\
137\end{array}$ & $\begin{array}{l}.000 \\
137\end{array}$ & 137 & $\begin{array}{l}1.000 \\
137\end{array}$ & $\begin{array}{l}1.000 \\
137\end{array}$ & $\begin{array}{l}1.000 \\
137\end{array}$ & $\begin{array}{l}.000 \\
1.000 \\
137\end{array}$ \\
\hline Excitement & $\begin{array}{l}\text { Pearson } \\
\text { Correlation } \\
\text { Sig. (2-tailed) } \\
\mathrm{N}\end{array}$ & $\begin{array}{l}.007 \\
137\end{array}$ & $\begin{array}{l}.607 \\
137\end{array}$ & $\begin{array}{l}.000 \\
1.000 \\
137\end{array}$ & 137 & $\begin{array}{l}.000 \\
1.000 \\
137\end{array}$ & $\begin{array}{l}1.000 \\
137\end{array}$ & $\begin{array}{l}.000 \\
1.000 \\
137\end{array}$ \\
\hline Relaxation & $\begin{array}{l}\text { Pearson } \\
\text { Correlation } \\
\text { Sig. (2-tailed) } \\
\mathrm{N}\end{array}$ & $\begin{array}{l}.000 \\
137\end{array}$ & $\begin{array}{l}.823 \\
137\end{array}$ & $\begin{array}{l}.000 \\
1.000 \\
137\end{array}$ & $\begin{array}{l}.000 \\
1.000 \\
137\end{array}$ & 137 & $\begin{array}{l}1.000 \\
137\end{array}$ & $\begin{array}{l}1.000 \\
137\end{array}$ \\
\hline
\end{tabular}

\footnotetext{
**. Correlation is significant at the 0.01 level (2-tailed).
} 
The results indicate that $\mathrm{H6}, \mathrm{H} 7, \mathrm{H} 8$ and $\mathrm{H} 10$ are accepted, which refers to the correlation between knowledge, excitement, relaxation and shopping, and attitude. Tourists aim to acquire knowledge and to enjoy relaxing moment in their travels, while shopping and excitement in their trips are also essential. However, the results show that H9 (associated "friends and family") is rejected, implying that friends and family living overseas would not significantly affect Hong Kong travelers and their travel attitude. H11 is also rejected, showing that there is no relationship between expectation and attitude. This is opposite to the EMA model. These results indicate that expectation in a tourist's mind is merely a belief and it would not directly affect a traveler's attitude. Thus, in order to affect a tourist's attitude, one must influence motivation.

\section{CONCLUSIONS AND IMPLICATIONS}

This study proves traveler expectation is correlated with knowledge, while knowledge, excitement, relaxation, and shopping significantly influence traveler attitude. This can explain how people make decisions when selecting a travelling destination. There is a stronger influence from motivational factors towards attitude, rather than from the traveler's expectation. Understanding motivation, expectation and attitude, will certainly help in segmenting markets, designing promotional programs and product offerings, and decision-making about destination development.

In terms of marketing efforts, tourism managers should utilize social media like Facebook to attract travelers and the trip content and service delivery should be enhanced to increase tourist motivation. Indeed, the motivation of potential tourists could be increased by promoting the attractiveness of the tours (i.e., carry a broad variety of activities and provide more customized travel packages); fostering close relationships with country governments and businesses; and maintaining an effective evaluation system.

A review of the literature has shown that over the past five years people in Hong Kong are increasingly taking outbound trips (Law, et al., 2011). As such, this study makes two important contributions. First, it has significant managerial implications for tourism practitioners and policymakers by furthering an understanding of the behavioral patterns of outbound travelers from Hong Kong. It is hoped that more quality services and products will be developed to meet the needs of this target segment. Second, this study aims to make a small, but yet, meaningful contribution to methodological development by further testing the EMA model through an examination of the relationships between motivation, expectation and attitude. As 
Hong Kong's outbound market continues to grow in size and sophistication, it is important to further understand the decision-making process of Hong Kong travelers in choosing a destination.

This study, however, does have its own limitations. A rather apparent limitation is its relatively small sample that is taken from a single geographical region, and thus, the findings of the study may not be generalized. The relatively young sample $(51.8 \%$ of respondents were aged between 19 and 29 years-old) challenges the validity of the study results, and calls for research efforts to verify the validity of the EMA model for other samples and destinations. Additionally, future research may consider proving the linkages between expectation and attitude. It should also be noted that motivation is only one of the possible variables that explains tourists' destination attraction attribute preference behavior. It would be interesting to consider comparative studies to unearth a more in-depth understanding of tourist behavior and motivation factors in different contexts, and to better generalize the results.

\section{REFERENCES}

Australian, Department of Tourism and Recreation. (1975). Development of Tourism in Australia. Canberra, Australia: Australian Government Publishing Service.

Backman, K., Backman, S., Uysal, M. and Sunshine, K. (1995). Event tourism: An examination of motivations and activities. Festival Management \& Event Tourism, 3(1), 15-24.

Baloglu, S. and Uysal, M. (1996). Market segments of push and pull motivations: A canonical correlation approach. International Journal of Contemporary Hospitality Management, 8(3), 32-38. http://dx.doi.org/10.1108/09596119610115989

Bandura, A. (1977). Analysis of Self-efficacy Theory of Behavioural Change. Cognitive Therapy and Research, 1, 287-308.

Berlyne, D.E. (1950). Novelty and Curiosity as Determinants of Exploratory Behaviour. British Journal of Psychology, 41(1), 68-80. http://dx.doi.org/10.1111/j.2044-8295.1950.tb00262.x

Census and Statistics Department. (2010). Hong Kong Monthly Digest of Statistics The Situation of the Four Key Industries in the Hong Kong Economy in 2008. Retrieved from http://www.statistics.gov.hk/pub/B71003FB2010XXXXB0100.pdf

Cha, S., McCleary, K. and Uysal, M. (1995). Travel motivations of Japanese overseas travelers: A factor-cluster segmentation approach. Journal of Travel Research, 34(1), 33-39. http://dx.doi.org/10.1177/004728759503400104 
Crompton, J. (1979). Motivations for Pleasure Vacation. Annals of Tourism Research, 6(4), 408-424. http://dx.doi.org/10.1016/0160-7383(79)90004-5

Dann G. (1977). Anomie, ego-enhancement and tourism. Annals of Tourism Research, 4(4), 184-194. http://dx.doi.org/10.1016/0160-7383(77)90037-8

Dunn, R. and Iso-Ahola, S. (1991). Sightseeing tourists: Motivation and Satisfaction. Annals of Tourism Research, 18(2), 226-237.

Fishbein, M., \& Ajzen, I. (1975). Belief, Attitude, Intention, and Behavior: An Introduction to Theory and Research, Reading, MA: Addison-Wesley.

Gnoth, J. (1997). Tourism Motivation and Expectation Formation.

Annals of Tourism Research, 24(2), 283-304. http://dx.doi.org/10.1016\%2FS0160-7383\%2897\%2980002-3

Hair, J.F., Anderson, R.E., Tatham, R.L. and Black, W.C. (1998). Multivariate Data Analysis ( $5^{\text {th }}$ ed.). Upper Saddle River, NJ: Prentice-Hall.

Heckhausen, H. (1989). Motivation and Action. Translated by P.K. Leppmann ( $2^{\text {nd }}$ ed.). Berlin , Germany: Springer-Verlag.

Higgins, E. (1996). Knowledge activation: Accessibility, Applicability, and Salience. In E.T. Higgins and A.W. Kruglanski (Eds.), Social Psychology: Handbook of Basic Principles (pp. 133-168). New York , NY: Guilford.

Hong Kong, Hong Kong Tourism Board. (2009). A Statistical Review of Hong Kong Tourism. Retrived from http://partnernet.hktb.com/pnweb/jsp/comm/ index.jsp?charset=en

Hsu, C.H.C., Cai, L.A., Li, M. (2010). Expectation, Motivation, and Attitude: A Tourist Behavioral Model. Journal of Travel Research, 49(3), 282-296. http://dx.doi.org/10.1177/0047287509349266

Jacob, B. and Ragheb, M. (1983). Measuring Leisure Motivation.

Journal of Leisure Research, 15(3), 219-228.

Jafari, J. (1977). Editor's Page. Annals of Tourism Research, (Sp. No.), (Vol. 5, pp. 6-11).

Kim, K., Oh, I. and Jogaratnam, G. (2007). College student travel: A revised model of push motives. Journal of Vacation Marketing, 13(1), 73-85. http://dx.doi.org/10.1177/1356766706071201

Klenosky, D. (2002). The pull of tourism destinations: A means-end investigation. Journal of Travel Research, 40(4), 385-395. http://dx.doi.org/10.1177/0047287502040004005

Lam, T. and Hsu, C. (2004). Theory of planned behavior: Potential travelers from China. Journal of Hospitality and Tourism Research, 28(4), 463-482. 
http://dx.doi.org/10.1177/1096348004267515

Lam, T. and Hsu, C. (2006). Predicting behavioral intention of choosing a travel destination. Tourism $\quad$ Management, 27(2), 589-599. http://dx.doi.org/10.1016/j.tourman.2005.02.003

Law, R., Rong, J., Vu, H., Li, G. and Lee, A. (2011). Identifying changes and trends in Hong Kong outbound tourism. Tourism Management, 32(5), 1106-1114. http://dx.doi.org/10.1016/j.tourman.2010.09.011

Lee, Y. and Chen, T. (2005). Traveling motivation and satisfaction of tourists: An empirical study of Taroko National Park in Taiwan. The Business Review, 4(2), 175-181. Cambridge, MA: Harvard.

Lee, S., Jeon, S. and Kim, D. (2011). The impact of tour quality and tourist satisfaction on tourist loyalty: The case of Chinese tourists in Korea. Tourism Management, 32(5), 1115-1124. http://dx.doi.org/10.1016/j.tourman.2010.09.016

Leiper, N. (1979). The framework of tourism. Annals of Tourism Research, 6(4), 390-407. http://dx.doi.org/10.1016\%2F0160-7383\%2879\%2990003-3

McCabe, A. (2000). Tourism motivation process. Annals of Tourism Research, 27(4), 1049-1052. http://dx.doi.org/10.1016/S0160-7383(99)00130-9

Mohammad, B. and Som, A. (2010). An analysis of push and pull travel motivations of foreign tourists to Jordan. International Journal of Business and Management, 5(12), 41-50.

Nunnally, J. C. \& Bernstein, I. H. (1994). Psychometric Theory ( $3^{\text {rd }}$ ed.). New York, NY: McGraw-Hill.

Chan, S. Y. Hong Kong Citizens spent 96 billion for Outbound Tour in past 9 Months. (2010, October 16). Oriental Daily.

Olson, J., Roese, N. and Zanna, M. (1996). Expectancies. In F.T. Higgins and A.W. Kruglanski (Eds.), Social Psychology: Handbook of Basic Principles (pp. 211-238). New York, NY: Guilford.

Pearce, P. (1988). The Ulysess Factor: Evaluation Visitors in Tourist Settings. New York , NY: Springer-Verlag.

The Intention of Outbound Tourism for Hong Kong People Increased (2010, September 7). Sing Dao Daily.

The Government of the Hong Kong Special Administrative Region, Commerce and Economic Development Bureau, Tourism Commission. (2006). Individual Visit Scheme. Retrieved from http://www.tourism.gov.hk/english/visitors/visitors_ind.html. Vroom, V. (1964). Work and Motivation. New York, NY: Wiley. 
Yoona, Y., Uysal, M. (2005). An Examination of the Effects of Motivation and Satisfaction on Destination Loyalty: A Structural Model. Tourism Management, 26 (1), 45-56. http://dx.doi.org/10.1016/j.tourman.2003.08.016 
